\title{
(2) OPEN ACCESS \\ Local sales restrictions significantly reduce the availability of menthol tobacco: findings from four Minnesota cities
}

\author{
Joanne D'Silva $\odot,{ }^{1}$ Joanne Moze, ${ }^{2}$ John H. Kingsbury, ${ }^{3}$ Rebecca K Lien, ${ }^{4}$ \\ Christine M Matter, Betsy Brock, ${ }^{5}$ Antwi Akom ${ }^{6,7}$
}

${ }^{1}$ Research, ClearWay Minnesota, Minneapolis, Minnesota, USA ${ }^{2}$ Center for Prevention, Blue Cross and Blue Shield of Minnesota, Eagan, Minnesota, USA

${ }^{3}$ Tobacco Prevention and Control, Minnesota Department of Health, Saint Paul, Minnesota, USA

${ }^{4}$ Statistics and Research, Professional Data Analysts, Minneapolis, Minnesota, USA ${ }^{5}$ Research, Association for Nonsmokers-Minnesota, Saint Paul, Minnesota, USA

${ }^{6}$ Social Innovation Lab, University of California San Francisco, San Francisco,

California, USA

${ }^{7}$ Africana Studies, San Francisco State University, San Francisco, California, USA

\section{Correspondence to} Dr Joanne D'Silva, Research, ClearWay Minnesota, Minneapolis, MN 55425, USA; jdsilva@clearwaymn.org

Received 18 December 2019 Revised 5 May 2020 Accepted 11 May 2020

\section{ABSTRACT}

Background In 2017 and 2018, Minneapolis, St. Paul, Duluth and Falcon Heights, Minnesota were among the first US cities to restrict the sale of menthol tobacco to adult-only stores. The study examined changes in the availability and marketing of these products following policy implementation.

Methods Retail store audits were conducted approximately 2 months pre-policy and post-policy implementation. Tobacco retail stores $(n=299)$ were sampled from tobacco licensing lists in Minneapolis, St. Paul, Duluth and Falcon Heights, as well as six comparison cities without menthol policies. The presence of menthol tobacco was assessed, along with the number of interior and exterior tobacco ads and promotions at each store.

Results The majority of policy intervention stores (grocery, convenience stores and pharmacies) were compliant (Minneapolis, 84.4\%; Duluth, 97.5\%; and St. Paul and Falcon Heights, $100.0 \%$ ) and did not sell menthol tobacco. In contrast, menthol tobacco was available in all comparison city stores, and most (96.0\%) exempted tobacco shops and liquor stores post-policy implementation. Two Minneapolis convenience stores added interior tobacco shops, allowing them to continue selling menthol tobacco. Significant decreases in menthol tobacco marketing post-policy were observed in the stores' interior in Minneapolis, St. Paul and Duluth $(p<0.001)$ and on the stores' exterior in Duluth $(p=0.023)$.

Conclusions Findings demonstrate high rates of compliance, indicating that sales restrictions can significantly reduce the availability of menthol tobacco. However, challenges to policy adherence underscore the need for continued monitoring and enforcement action.

\section{INTRODUCTION}

Menthol cigarettes remain widely available ${ }^{1}$ despite overwhelming evidence that supports their removal from the marketplace. ${ }^{2-5}$ Menthol was the only flavour exempted from the US 2009 Family Smoking Prevention and Tobacco Control Act ban on flavoured cigarettes, although menthol cigarettes make up 36\% of cigarette sales. ${ }^{6}$ Menthol cigarettes are linked to increased initiation and decreased quitting, and are disproportionately marketed to African-American youth and other targeted subgroups. ${ }^{247}$ Menthol is also present in other tobacco (tobacco refers specifically to the use of manufactured, commercial tobacco products and not to the sacred, medicinal and traditional use of tobacco by American Indians and other groups) products, and recent evidence indicates an increase in youth preference for menthol-flavoured e-cigarettes. $^{8}$ The WHO has recommended prohibiting menthol in other tobacco products. ${ }^{5}$

In the absence of a US federal ban on menthol (as of April 2020), US cities are exercising their authority to enact sales restrictions on menthol tobacco. In 2017 and 2018, four Minnesota cities-Minneapolis, St. Paul, Duluth and Falcon Heights-passed ordinances restricting the sale of menthol, mint, and wintergreen tobacco, including e-cigarettes, to adult-only tobacco shops and liquor stores. ${ }^{9}$ In Minneapolis and St. Paul, menthol exemptions were removed from previous flavoured tobacco sales restrictions implemented in 2016. These menthol policies are intended to reduce youth access to these products by limiting sales through fewer outlets (from 670 to 178 across all four cities). ${ }^{10}$

Tobacco sales restrictions began gaining momentum following the issuance of the Food and Drug Administration (FDA)'s 2013 report. Although the report concluded that menthol cigarette use is likely associated with increased initiation and progression to regular cigarette smoking, increased nicotine dependence and reduced success in smoking cessation, especially among AfricanAmerican menthol smokers, ${ }^{3}$ the FDA has not exercised its regulatory authority to ban menthol cigarettes. The Minnesota menthol policies examined in this study include partial restrictions with exemptions for tobacco shops (stores with 90\% of sales derived from tobacco and tobacco-related devices) $)^{11}$ and additional exemptions for adultonly liquor stores in Minneapolis and St. Paul. Preceding these policies, Chicago passed the first menthol policy in 2013, which created a buffer zone of 500 feet around all schools where menthol tobacco cannot be sold; the policy was later rolled back to include only buffer zones around city high schools. ${ }^{12}$ More recently, cities including San Francisco have been successful in enacting a complete city-wide ban on menthol and other flavoured tobacco sales. ${ }^{13}$ To date, over 90 cities and other local jurisdictions have enacted either partial or full restrictions (bans) on sales of menthol tobacco. ${ }^{14}$

Given the growing momentum of menthol tobacco sales restrictions, there is a need to document how these policies change the retail environment. Previous evaluations of non-menthol flavoured tobacco sales restrictions have found that 
these types of policies can be effective in reducing the availability of flavoured tobacco products. ${ }^{15-17}$ However, because menthol has often been excluded from sales restrictions, there is a paucity of published literature about the impact of menthol tobacco sales restrictions on the retail environment. We are only aware of one published study to date that examined the impact of a menthol tobacco restriction on the retail environment. Czaplicki et $\mathrm{al}^{18}$ conducted retail store assessments 1 year following the implementation of the Chicago buffer zone menthol policy and found that over $40 \%$ of tobacco retail stores were noncompliant, continuing to sell Newport cigarettes, the primary outcome measure. ${ }^{18}$ Moreover, the study found a significant positive association between non-compliance and the presence of menthol cigarette advertising. Further research is needed to evaluate whether sales restrictions also impact advertising, even though these menthol policies do not include any language on advertising restrictions.

Recent studies have also demonstrated that the tobacco industry has attempted to undermine intended flavoured tobacco policy effects by introducing products with ambiguous names or concept flavours (such as Show 'TaTa' cigarillos and Rock ' $n$ ' Roll 'Blue' cigars) in New York City ${ }^{19}$ and replacing products previously labelled as menthol with the word 'green' in Ontario, Canada. ${ }^{20}$ These studies suggest it is important not only to assess compliance with menthol tobacco restrictions but also to monitor unintended consequences and potential tactics to circumvent restrictions following policy implementation.

The present study builds on the previous literature by examining changes in the availability and marketing of menthol tobacco in four Minnesota cities using a quasi-experimental design. Specifically, this study builds on the Czaplicki et al ${ }^{18}$ study in two important ways. First, this study assesses compliance with the policy as it applies to all menthol tobacco (not just menthol cigarettes). Second, it uses a design that includes baseline data pre-policy, as well as observations from comparison cities to assess changes in menthol tobacco availability and menthol tobacco marketing. Findings can inform other jurisdictions and US Food and Drug Administration regulatory action on menthol tobacco to reduce the burden of tobacco use.

\section{METHODS}

\section{Design}

This observational study used a pre/post-comparison group design. Retail store audits were conducted approximately 2 months before and after policy implementation in each of the four intervention cities: Minneapolis, St. Paul, Duluth and Falcon Heights (figure 1). Audits were also conducted in stores in six comparison Minnesota cities (table 1), selected based on similar resident demographic characteristics (median age, median household income, percent black/African-American, percent white and percent Hispanic) and the lack of a menthol tobacco sales restriction.

\section{Sample}

Data were collected between May 2018 and January 2019 (figure 1). A random sample of stores $(n=299)$ stratified by city and store type was drawn from licensing lists obtained from the Minnesota Department of Revenue in April 2018. The sample size in each intervention city and comparison city was selected to detect a $50 \%$ difference in the proportion of stores that were selling menthol tobacco post-policy (primary outcome) (G*Power V.3.1.9.2). In Falcon Heights, a small city with only three convenience stores, all three stores were included. A total of 288 stores had a completed assessment in the pre-policy, postpolicy or both time points (table 1). In addition to store types

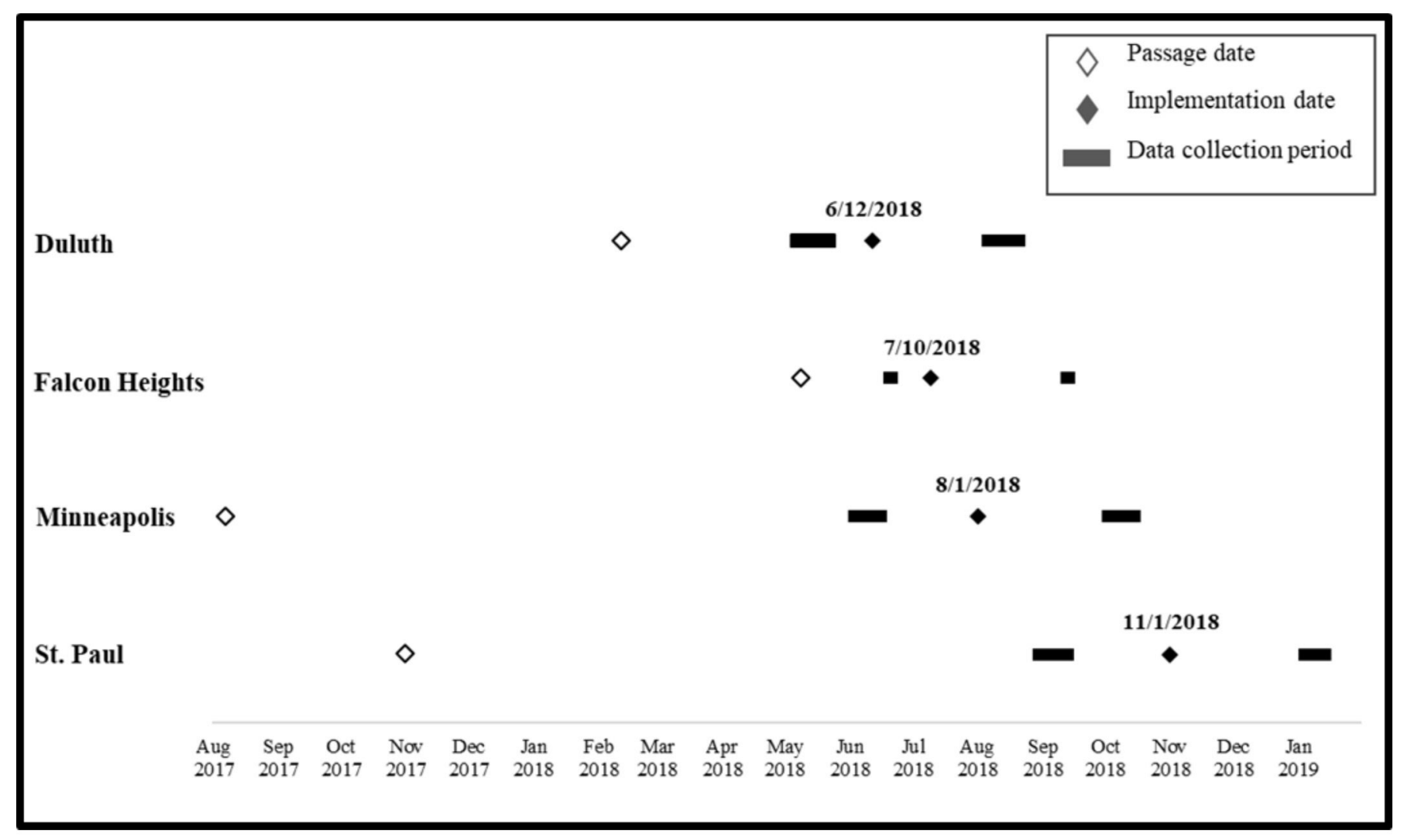

Figure 1 Menthol policy and data collection timeline for Duluth, Falcon Heights, Minneapolis, and St. Paul. 


\begin{tabular}{|c|c|c|c|c|c|}
\hline \multirow{2}{*}{$\begin{array}{l}\text { Policy city } \\
\text { Comparison city }\end{array}$} & \multirow[b]{2}{*}{$\begin{array}{l}\text { Total } \\
\text { sample }\end{array}$} & \multicolumn{4}{|c|}{$\begin{array}{l}\text { Number of stores } \\
\text { (intervention and exempted combined) }\end{array}$} \\
\hline & & $\begin{array}{l}\text { Pre and } \\
\text { Post }\end{array}$ & Pre only & Post only & $\begin{array}{l}\text { Neither pre } \\
\text { nor post }\end{array}$ \\
\hline Duluth & 63 & 43 & 7 & 6 & 7 \\
\hline Mankato & 18 & 17 & 1 & 0 & 0 \\
\hline Winona & 18 & 15 & 2 & 1 & 0 \\
\hline Falcon Heights & 3 & 3 & 0 & 0 & 0 \\
\hline Minneapolis & 61 & 59 & 1 & 0 & 1 \\
\hline Brooklyn Park & 19 & 18 & 1 & 0 & 0 \\
\hline Maplewood & 18 & 17 & 1 & 0 & 0 \\
\hline St. Paul & 62 & 60 & 0 & 0 & 2 \\
\hline Burnsville & 18 & 18 & 0 & 0 & 0 \\
\hline Fridley & 19 & 18 & 0 & 0 & 1 \\
\hline Total stores & 299 & 268 & 13 & 7 & 11 \\
\hline
\end{tabular}

closed $(n=4)$, ineligible store type $(n=1)$, unsafe environment $(n=1)$ and other $(n=1)$.

(eg, convenience and grocery stores) where the policy restricted menthol tobacco sales, a smaller sample of assessments was conducted in exempted stores that were allowed to continue selling menthol tobacco post-policy: Duluth, tobacco shops $(\mathrm{n}=2)$; Minneapolis, tobacco shops $(\mathrm{n}=6)$ and liquor stores $(\mathrm{n}=6)$; and St. Paul, tobacco shops $(\mathrm{n}=6)$ and liquor stores $(\mathrm{n}=5)$.

\section{Procedures}

In most cities, pairs of trained data collectors independently conducted discreet (unannounced) observational assessments of the retail environment and entered data into an online data collection system (Streetwyze.com). Prior to conducting assessments, data collectors completed training on assessing the retail environment, recording data on Streetwyze via mobile phone, and conducted field practice on stores not included in the study. Any discrepancies were resolved through discussion, and the results were combined. Per cent agreement for selling menthol was $100 \%$ pre-policy (kappa NA) and $94.5 \%$ postpolicy (kappa $=0.908)$. Intraclass correlation coefficients (ICCs) for number of interior tobacco ads were 0.917 pre-policy and 0.923 post-policy. For exterior tobacco ads, ICCs were 0.971 pre-policy and 0.989 post-policy.

\section{Measures}

The assessment tool was based on the Standardized Tobacco Assessment for Retail Settings (STARS). ${ }^{21}$ The STARS tool was developed as a retail marketing monitoring and policy advocacy tool; measures for this study were adapted for policy evaluation purposes.

\section{Menthol tobacco availability}

Policy compliance was measured using the assessment item 'What type of menthol/mint/wintergreen tobacco products are sold here?'. Response options included cigarettes, cigars, cigarillos or little cigars, e-cigarettes, smokeless tobacco, shisha/ hookah, blunt wraps and roll your own. A response to any of the menthol tobacco product types indicated that menthol tobacco was sold at the store.

\section{Ambiguous menthol tobacco}

The availability of potential replacement menthol tobacco was assessed using the item 'Does the store sell tobacco products with ambiguous names such as "green" or "smooth"?', as was observed in prior research. ${ }^{19} 20$

\section{Tobacco marketing}

Number of advertisements and promotions, including digital or print signs on windows, counters, gas pumps, sidewalks, on display cases, behind the counter, in the interior and exterior of stores were also captured during the assessments. Advertisements were categorised as menthol or non-menthol tobacco marketing. Advertisements that showed both menthol and nonmenthol products or the Newport name only were categorised as menthol marketing.

\section{Store types}

Stores were categorised as intervention (convenience, grocery, pharmacy and other) and exempted stores (tobacco shops in Minneapolis, St. Paul and Duluth; and liquor stores in Minneapolis and St. Paul). Exempted stores were preliminarily categorised into store type using online searches and subsequently confirmed by the data collectors as part of the assessment. In Minneapolis, data collectors identified two stores post-policy that created separate internal tobacco shops within their store, allowing them to continue selling menthol tobacco. These stores were treated as exempted stores in the post-policy analysis.

\section{Analysis}

The analysis included descriptive statistics, $\chi^{2}$ tests to assess differences in independent groups and paired t-tests for testing differences within the same group across two time periods. Differences in aggregate demographic characteristics of policy city store neighbourhoods and comparison city store neighbourhoods were assessed using overlapping CIs. All analysis was conducted in SAS V.9.4.

\section{RESULTS}

\section{Menthol tobacco availability}

Among intervention stores post-policy, all stores in the St. Paul and Falcon Heights sample had stopped selling menthol tobacco

\begin{tabular}{|c|c|c|c|c|}
\hline \multirow{2}{*}{$\begin{array}{l}\text { Policy city } \\
\text { Comparison city }\end{array}$} & \multirow[b]{2}{*}{$\begin{array}{l}\text { Stores } \\
\text { (n) }\end{array}$} & \multirow{2}{*}{$\begin{array}{l}\text { Stores selling } \\
\text { menthol } \\
\text { tobacco pre- } \\
\text { policy }(\%)\end{array}$} & \multirow{2}{*}{$\begin{array}{l}\text { Stores selling } \\
\text { selling menthol } \\
\text { tobacco post- } \\
\text { policy }(\%)\end{array}$} & \multirow{2}{*}{$\begin{array}{l}\text { Policy } \\
\text { compliance } \\
\text { rates (\%) }\end{array}$} \\
\hline & & & & \\
\hline Duluth & 40 & 100.0 & 2.5 & 97.5 \\
\hline Mankato & 15 & 100.0 & 100.0 & NA \\
\hline Winona & 14 & 100.0 & 100.0 & NA \\
\hline Falcon Heights & 3 & 100.0 & 0.0 & 100.0 \\
\hline Minneapolis & 45 & 100.0 & 15.6 & 84.4 \\
\hline Brooklyn Park & 16 & 100.0 & 100.0 & NA \\
\hline Maplewood & 14 & 100.0 & 100.0 & NA \\
\hline St. Paul & 49 & 98.0 & 0.0 & 100.0 \\
\hline Burnsville & 14 & 100.0 & 100.0 & NA \\
\hline Fridley & 15 & 100.0 & 100.0 & NA \\
\hline
\end{tabular}

Includes intervention stores (ie, excludes exempted stores) as well as comparison stores with both a pre-policy and post-policy assessment. Missing menthol tobacco availability: Duluth $(n=1)$.

NA, not applicable. 
(table 2). One Duluth store (2.5\%) and seven Minneapolis stores $(15.6 \%)$ were selling menthol tobacco post-policy. Among the eight non-compliant stores, five sold menthol cigarettes; one sold menthol smokeless; one sold menthol e-cigarettes; and one sold menthol roll your own tobacco. Most non-compliant stores (88\%) were convenience stores and $38 \%$ were convenience stores that sold gas.

Menthol tobacco was available in almost all (96\%) exempted stores (adult tobacco shops, liquor stores) compared with $6 \%$ of intervention stores $(\mathrm{p}<0.001)$ post-policy implementation. All stores in the comparison cities continued selling menthol tobacco before and after the policy changes. No products with ambiguous names or replacement menthol tobacco were observed in the overall sample.

Differences in demographic characteristics among the neighbourhoods where sampled stores were located were assessed to determine comparability between intervention and comparison cities. We found that the median age was lower in Minneapolis ( $32 \pm 2$ years) than both comparison cities Brooklyn Park (40 \pm 5 years) and Maplewood (39 \pm 3 years). Minneapolis neighbourhoods had a higher proportion of black/African-American residents than Maplewood (23\% $\pm 5 \%$ vs 9\% $0 \pm \%$ ). St. Paul neighbourhoods had a lower median income and lower proportion of white residents than Burnsville ( $\$ 48000 \pm \$ 5000$ vs $\$ 76000 \pm \$ 9000$ and $48 \% \pm 6 \%$ vs $69 \% \pm 5 \%$, respectively). There were no other significant differences in aggregate neighbourhood characteristics.

\section{Tobacco marketing}

The number of interior advertisements and promotions for menthol tobacco decreased between pre-policy and post-policy for Duluth, Minneapolis and St. Paul intervention stores (ps<0.001) (table 3). The number of exterior advertisements and promotions for menthol tobacco decreased significantly for Duluth $(\mathrm{p}=0.023)$, but not for Minneapolis or St. Paul. Falcon Heights was not tested due to small sample size.

For non-menthol tobacco, the number of interior advertisements and promotions increased for Duluth, Minneapolis and St. Paul ( $\mathrm{p} \leq 0.001)$ (table 3$)$. No changes were seen in exterior ads for non-menthol tobacco before and after policy changes.

\section{DISCUSSION}

To our knowledge, this study is among the first to examine the impact of menthol tobacco sales restrictions on the retail environment using a quasi-experimental design. Our results indicate a high rate of compliance across all four policy cities, indicating that menthol tobacco sales restrictions can significantly reduce the availability of menthol tobacco in tobacco retail stores. Study findings suggest that these sales restrictions can also significantly reduce menthol tobacco marketing at the point of sale, potentially reducing youth exposure to tobacco industry marketing.

Compared with the $57 \%$ compliance rate observed in the evaluation of Chicago's buffer-zone policy around schools, ${ }^{18}$ we observed higher rates of compliance with menthol tobacco sales restrictions in four Minnesota cities (84\%-100\% compliance). Prior work examining the impact of the 2015 Minneapolis and St. Paul flavoured (exempting menthol) restrictions found similar rates of compliance within 9 months of policy implementation. ${ }^{15}$ In these cities, it is plausible that educational and enforcement activities by advocates and city officials associated with the 2015 flavoured restrictions, and ahead of the menthol tobacco sales

Table 3 Average number of menthol and non-menthol interior tobacco ads and exterior tobacco ads in intervention and comparison stores prepolicy versus post-policy ( $\mathrm{N}=226)$

\begin{tabular}{|c|c|c|c|c|c|c|c|}
\hline \multirow{2}{*}{$\begin{array}{l}\text { Policy city } \\
\text { Comparison city }\end{array}$} & \multirow{2}{*}{$\begin{array}{l}\mathrm{N} \\
\text { (total pairs) }\end{array}$} & \multicolumn{2}{|c|}{ Menthol tobacco ads } & \multirow[b]{2}{*}{ P value* } & \multicolumn{2}{|c|}{ Non-menthol tobacco ads } & \multirow[b]{2}{*}{$P$ value* } \\
\hline & & Pre-policy & Post-policy & & Pre-policy & Post-policy & \\
\hline \multicolumn{8}{|l|}{ Interior ads } \\
\hline Duluth & 39 & $2.64(2.49)$ & $0.10(0.50)$ & $<0.001$ & $7.24(7.12)$ & $15.03(14.10)$ & $<0.001$ \\
\hline Mankato & 15 & $3.67(2.38)$ & $5.07(2.87)$ & & $4.87(3.38)$ & $11.60(8.43)$ & \\
\hline Winona & 13 & $4.00(3.49)$ & $6.23(4.66)$ & & $6.38(8.68)$ & $17.46(14.55)$ & \\
\hline Falcon Heights & 3 & $6.33(7.09)$ & 0.00 (NA) & & $14.83(12.85)$ & $18.50(16.86)$ & \\
\hline Minneapolis & 45 & $5.10(3.66)$ & $0.33(0.69)$ & $<0.001$ & $7.74(6.41)$ & $12.36(9.69)$ & 0.001 \\
\hline Brooklyn Park & 16 & $6.43(4.42)$ & $6.97(5.04)$ & & $13.25(9.28)$ & $16.31(11.26)$ & \\
\hline Maplewood & 14 & $6.64(2.96)$ & $9.25(3.44)$ & & 11.68 & 12.82 & \\
\hline St. Paul & 49 & $7.10(3.41)$ & $0.91(2.61)$ & $<0.001$ & $10.60(6.66)$ & $15.53(9.40)$ & $<0.001$ \\
\hline Burnsville & 13 & $9.58(5.24)$ & $7.62(4.90)$ & & $20.84(10.25)$ & $20.62(11.28)$ & \\
\hline Fridley & 15 & $8.33(4.50)$ & $9.27(4.08)$ & & $11.90(6.38)$ & $9.87(6.39)$ & \\
\hline \multicolumn{8}{|l|}{ Exterior ads } \\
\hline Duluth & 41 & $0.24(0.66)$ & 0.00 (NA) & 0.023 & $0.61(1.45)$ & $1.05(3.55)$ & 0.437 \\
\hline Mankato & 14 & $0.64(1.28)$ & $0.36(1.08)$ & & $0.36(0.74)$ & $0.57(1.02)$ & \\
\hline Winona & 14 & $0.07(0.27)$ & $0.29(0.83)$ & & $0.21(0.43)$ & $0.21(0.58)$ & \\
\hline Falcon Heights & 3 & 0.00 (NA) & $3.00(5.20)$ & & $2.67(4.62)$ & 0.00 (NA) & \\
\hline Minneapolis & 44 & $0.30(0.95)$ & $0.13(0.31)$ & 0.259 & $0.61(1.14)$ & $0.62(1.13)$ & 0.957 \\
\hline Brooklyn Park & 16 & $0.34(0.57)$ & $0.19(0.40)$ & & $1.00(1.62)$ & $1.81(3.19)$ & \\
\hline Maplewood & 14 & $0.43(0.76)$ & $0.50(0.65)$ & & $0.75(1.16)$ & $2.07(2.97)$ & \\
\hline St. Paul & 48 & $0.20(0.76)$ & $0.05(0.21)$ & 0.212 & $1.93(3.60)$ & $1.27(1.77)$ & 0.094 \\
\hline Burnsville & 13 & $0.40(0.64)$ & $0.96(2.36)$ & & $2.21(3.17)$ & $2.39(2.42)$ & \\
\hline Fridley & 15 & $0.33(0.82)$ & $0.40(0.91)$ & & $3.33(4.78)$ & $2.00(2.39)$ & \\
\hline
\end{tabular}

Cell entries are sample size (n) or mean (SD) of interior and exterior ads. Missing assessments for interior ads: Duluth ( $n=2)$, Winona ( $n=1)$ and Burnsville ( $n=1)$. Missing assessments for exterior ads: Mankato $(n=1)$, Minneapolis $(n=1)$, St. Paul $(n=1)$ and Burnsville $(n=1)$.

*Paired t-test.

NA, not applicable. 
restriction implementation date, prepared retailers to adhere to the menthol tobacco sales restriction and resulted in relatively high rates of compliance.

Similar to the Czaplicki $e t$ al ${ }^{18}$ study, we did not find any products with ambiguous names or products designed to replace menthol tobacco, as was observed in Alberta, Canada. ${ }^{20}$ However, other challenges to policy adherence remain. For example, data collectors noted that two convenience stores in Minneapolis erected walls and created split stores (ie, separate tobacco shops within the convenience store). The emergence of these types of establishments underscores the challenges to a menthol tobacco sales restriction with exemptions. In June 2018, the city of Minneapolis reported that some convenience stores converted to tobacco shops, resulting in a $108 \%$ increase in the number of tobacco shops (from 25 to 52). ${ }^{22}$ Minneapolis responded by issuing a 1-year moratorium on new tobacco shops and later instituting a $2000 \mathrm{ft}$ spacing requirement between tobacco shops. Unlike a comprehensive ban on menthol tobacco, exemptions offer opportunities for tobacco retail stores to circumvent the intended impact of the policy. Therefore, it is important not only to monitor compliance with the menthol tobacco sales restriction but to ensure that tobacco shops are adhering to Minnesota state regulations that mandate an entrance door opening to the outside and deriving 90\% of its sales from tobacco in order to qualify for the tobacco shop exemption. Moreover, menthol tobacco and marketing continued to be available in exempted tobacco shops and liquor stores, as well as in the comparison cities, highlighting opportunities for policymakers to expand regulations both within the four intervention cities and across the state, which could help address cross-border concerns.

It is notable that the menthol tobacco sales restrictions led to some decreases in menthol tobacco marketing. Historically, restrictions on advertising have been challenging to pursue given constitutional free speech protections and legal challenges. ${ }^{23}$ However, as might be expected, decreases in interior menthol tobacco marketing were offset by an increase in non-menthol tobacco marketing. Because tobacco marketing is associated with youth smoking initiation and progression, ${ }^{24}$ strategies to reduce youth exposure to advertising and promotions at the point of sale are imperative. In 2016, the tobacco industry spent $\$ 9.5$ billion in marketing expenses nationwide; in Minnesota, the tobacco industry spent over $\$ 117$ million, ${ }^{25}$ with the majority spent at the point of sale. While there was no decrease in the mean number of menthol tobacco exterior ads in Minneapolis and St. Paul, the mean number of exterior ads across all cities was low overall (less than one, both pre-policy and post-policy).

This study has several limitations and strengths to note. First, our findings are limited to four Minnesota cities and may not be generalisable to other jurisdictions. Second, data collection occurred 2 months prior to and following policy implementation, which could have impacted study findings. Ongoing monitoring will be necessary to assess whether high levels of compliance are sustained over time. However, short-term data are valuable to identify implementation challenges and to inform compliance officers and other city officials of resources needed for policy implementation. Future studies should also examine sales data to validate study findings and to measure the impact of menthol tobacco sales restrictions on behaviour. A study examining Ontario's menthol tobacco ban found that it substantially increased quit attempts at 1 -month follow-up. ${ }^{26}$ In addition, longitudinal studies are needed to assess how menthol tobacco availability and exposure to menthol tobacco marketing impact initiation and long-term cessation outcomes, especially for African-Americans who are disproportionately impacted by menthol smoking.

Notwithstanding these limitations, our study provides valuable information about the impact of partial menthol tobacco sales restrictions. Menthol tobacco is no longer available in a majority of tobacco retail stores, and the sales restrictions resulted in reductions in interior menthol tobacco marketing. Despite high levels of compliance in Minneapolis, St. Paul, Duluth and Falcon Heights, menthol tobacco continues to be available in some non-compliant intervention stores, as well as all exempted tobacco shops and liquor stores. These findings suggest that removing existing retailer exemptions provide opportunities for policymakers to further reduce menthol tobacco availability. Ongoing monitoring of compliance is also warranted to ensure that retailer efforts to circumvent policies are minimised so policies are implemented as intended for maximum public health benefit.

What this paper adds

What is already known on this subject

- In the absence of a US federal ban on menthol, US cities are exercising their authority to enact sales restrictions on menthol tobacco.

What important gaps in knowledge exist on this topic

- Limited prior research has examined the impact of menthol tobacco sales restrictions on menthol availability and marketing in the retail environment.

What this paper adds

- Findings demonstrate high rates of compliance with the menthol tobacco sales restrictions in Minneapolis, St. Paul, Duluth and Falcon Heights, indicating that sales restrictions can significantly reduce the availability of menthol tobacco.

Acknowledgements We acknowledge the contributions of Barbara Schillo, Tessa Cruz, Aekta Shah, the data collection team and the Minnesota Menthol Evaluation Advisory Group. We also thank Dr Raymond Boyle, Dr Craig S. Fryer, Dr Kenneth Beck, Dr James Butler III, Dr Min Qi Wang and Dr Jie Chen for their insights. Finally, we thank the advocates in Duluth, Falcon Heights, Minneapolis and St. Paul for their ongoing efforts to keep our young people healthy and improve the health and lives of our communities.

Contributors JD, JM, CM and JK conceived the original idea for this study. RL conducted data analysis. JD, JM, JK and RL interpreted the data. JD wrote the initial draft and received input from coauthors on the initial version as well as revisions of the manuscript. All authors read, reviewed and approved the final version.

Funding This study was funded by ClearWay Minnesota and the Center for Prevention at Blue Cross and Blue Shield of Minnesota. Support was also provided in part by Truth Initiative.

Competing interests None declared.

Patient consent for publication Not required.

Provenance and peer review Not commissioned; externally peer reviewed.

Data availability statement Data are available upon reasonable request from the corresponding author.

Open access This is an open access article distributed in accordance with the Creative Commons Attribution Non Commercial (CC BY-NC 4.0) license, which permits others to distribute, remix, adapt, build upon this work non-commercially, and license their derivative works on different terms, provided the original work is properly cited, appropriate credit is given, any changes made indicated, and the use is non-commercial. See: http://creativecommons.org/licenses/by-nc/4.0/.

\section{ORCID iD}

Joanne D'Silva http://orcid.org/0000-0003-1139-4140 


\section{REFERENCES}

1 Lee JGL, Henriksen L, Rose SW, et al. A systematic review of neighborhood disparities in Point-of-Sale tobacco marketing. Am J Public Health 2015;105:e8-18.

2 Tobacco Products Scientific Advisory Committee. Menthol cigarettes and public health: review of the scientific evidence and recommendations, 2011. Available: https:/www. fda.gov/downloads/AdvisoryCommittees/CommitteesMeetingMaterials/TobaccoProdu ctsScientificAdvisoryCommittee/UCM247689.pdf

3 U.S. Food and Drug Administration. Preliminary scientific evaluation of the possible public health effects of menthol versus Nonmenthol cigarettes, 2013. Available: https://www.fda.gov/media/86497/download [Accessed 18 Mar 2020].

4 Villanti AC, Collins LK, Niaura RS, et al. Menthol cigarettes and the public health standard: a systematic review. BMC Public Health 2017;17:983.

5 World Health Organization. Advisory note: banning menthol in tobacco products, 2016. Available: http://www.who.int/tobacco/publications/prod_regulation/mentholadvisory-note/en/ [Accessed 31 Mar 2018].

6 Federal Trade Commission. Federal Trade Commission cigarette report for 2017, 2019. Available: https://www.ftc.gov/system/files/documents/reports/federal-tradecommission-cigarette-report-2017-federal-trade-commission-smokeless-tobaccoreport/ftc_cigarette_report_2017.pdf [Accessed 18 Mar 2020].

7 Gardiner PS. The African Americanization of menthol cigarette use in the United States. Nicotine Tob Res 2004;6(Suppl 1):55-65.

8 Cullen KA, Ambrose BK, Gentzke AS, et al. Notes from the Field: Use of Electronic Cigarettes and Any Tobacco Product Among Middle and High School Students United States, 2011-2018. MMWR Morb Mortal Wkly Rep 2018;67:1276-7.

9 ClearWay Minnesota, Center for Prevention at Blue Cross and Blue Shield of Minnesota. How Minneapolis, St. Paul and Duluth passed Nation-Leading menthol tobacco sales restrictions: case studies from Minnesota, 2019. Available: https://www. centerforpreventionmn.com/wp-content/uploads/2019/02/Menthol-Case-StudiesMinneapolis-St.-Paul-Duluth-FINAL.pdf [Accessed 18 Mar 2020].

10 March 18, 2020ClearWay Minnesota, Center for Prevention at Blue Cross and Blue Shield of Minnesota. How Minneapolis, St. Paul, Duluth and falcon heights are implementing menthol tobacco restrictions: experiences from Minnesota; 2020. https://www.centerforpreventionmn.com/wp-content/uploads/2020/02/ImplementingMenthol-Tob-Restrictions.pdf

11 Minnesota Department of Health. Tobacco product shops. Available: https://www. health.state.mn.us/communities/environment/air/mciaa/tobacco.html [Accessed 18 Mar 2020].

12 Tobacco Control Legal Consortium. Chicago's regulation of menthol flavored tobacco products: a case study. Available: https://www.publichealthlawcenter.org/sites/default/ files/resources/tclc-fs-Chicago-Regulation-of-Menthol-Case-Study-Update-2016.pdf [Accessed 18 Mar 2020].
13 LaVito A. San Francisco approves ban on menthol cigarettes and flavored e-cigarette liquids. Available: https://www.cnbc.com/2018/06/06/san-francisco-approves-ban-onmenthol-cigarettes-and-flavored-e-cigarette-liquids.html [Accessed 18 Mar 2020].

14 Campaign for Tobacco Free Kids. States \& Localities That Have Restricted the Sale of Flavored Tobacco Products, 2020. Available: https://www.tobaccofreekids.org/assets/ factsheets/0398.pdf [Accessed 18 Mar 2020].

15 Brock B, Carlson SC, Leizinger A, et al. A tale of two cities: exploring the retail impact of flavoured tobacco restrictions in the twin cities of Minneapolis and Saint Paul, Minnesota. Tob Control 2019;28:176-80.

16 Rogers T, Brown EM, McCrae TM, et al. Compliance with a sales policy on flavored Non-cigarette tobacco products. Tob Regul Sci 2017;3:84-93.

17 Kephart L, Setodji C, Pane J, et al. Evaluating tobacco retailer experience and compliance with a flavoured tobacco product restriction in Boston, Massachusetts: impact on product availability, advertisement and consumer demand. Tob Control 2019. doi:10.1136/tobaccocontrol-2019-055124. [Epub ahead of print: 14 Oct 2019].

18 Czaplicki L, Cohen JE, Jones MR. Compliance with the City of Chicago's partial ban on menthol cigarette sales. Tob Control 2018:tobaccocontrol-2018-054319.

19 Farley SM, Johns M. New York City flavoured tobacco product sales ban evaluation. Tob Control 2017;26:78-84.

20 Brown J, DeAtley T, Welding K, et al. Tobacco industry response to menthol cigarette bans in Alberta and nova Scotia, Canada. Tob Control 2017;26:e71-4.

21 Henriksen L, Ribisl KM, Rogers T, et al. Standardized tobacco assessment for retail settings (STARS): dissemination and implementation research. Tob Control 2016;25:i67-74.

22 City of Minneapolis. Tobacco density study. tobacco density study June 2019, 2019. Available: https://lims.minneapolismn.gov/Download/File/2550/Tobacco\%20Density\% 20Study\%20updated.pdf [Accessed 18 Mar 2020].

23 National Cancer Institute. The role of the media in promoting and reducing tobacco use. Tobacco control monograph No. 19. Bethesda, MD: U.S. Department of Health and Human Services, National Institutes of Health, National Cancer Institute, Published 2008.

24 U.S. Department of Health and Human Services. Preventing tobacco use among youth and young adults: a report of the surgeon General, 2012. Available: https:// www.surgeongeneral.gov/library/reports/preventing-youth-tobacco-use/index.html [Accessed 18 Mar 2020].

25 Campaign for Tobacco Free Kids. Broken promises to our children: a State-by-State look at the 1998 tobacco settlement 20 years later, 2017. Available: https://www. tobaccofreekids.org/what-we-do/us/statereport [Accessed 18 Mar 2020].

26 Chaiton M, Schwartz R, Cohen JE, et al. Association of Ontario's ban on menthol cigarettes with smoking behavior 1 month after implementation. JAMA Intern Med 2018;178:710. 